\title{
THE EXCHANGE OF LIPIDS IN THE UMBILICAL CIRCULATION AT BIRTH
}

\author{
By ELDON M. BOYD ${ }^{1}$ AND KARL M. WILSON \\ (Department of Obstetrics and Gynecology, The University of Rochester, \\ School of Medicine and Dentistry, Rochester, New York)
}

(Received for publication July 11, 1934)

Pregnancy in women has been shown by Boyd (1) to be accompanied by a lipemia involving certain definite changes in the lipid concentration of the red blood cells and blood plasma. Correlating this with earlier work the conclusion was reached that the increase in the concentration of blood lipids commences about midway in the nine months of gestation. Fat metabolism in the fetus also becomes active about the mid-point of pregnancy as indicated by increasing amounts of lipids being laid down in the growing offspring (2). The time relationship of these two processes suggests that they may be related.

To prove or disprove this possible relation was the purpose of the present investigation. As a working hypothesis it was suggested that as the lipid concentration in the maternal blood stream increases, the placenta passes more of these substances on to umbilical blood from whence they are absorbed in increasing amounts by the fetus. This theory requires proof (a) that lipids are absorbed from umbilical blood by the fetus, and (b) that lipids are added to umbilical blood by the placenta. The placenta of the rabbit and rat has been shown in recent years to be "permeable" to lipids by Bickenbach and Rupp (14), Sinclair (15) and Chaikoff and Robinson (16). By analogy the human placenta has been assumed to be "permeable" also. Direct proof of the "permeability" of the human placenta to lipids is lacking and it should be recalled that the structure of the human placenta differs from that of the rat and the rabbit. In fact Slemons and Stander (3) and many others as reviewed by Needham (2), Mayer (4), Schlossmann (5), etc., believe that the human placenta does not permit the passage of fats to the fetal circulation because they found that the lipid concentration of blood on the maternal side of the placenta was always higher than

\footnotetext{
1 Faculty of Medicine, Queen's University, Kingston, Ontario, Canada.
}

on the fetal side. We have repeated this experiment and obtained similar results but we are inclined to agree with Needham (2) that it does not prove the human placenta to be "impermeable" to lipids. Hence we devised experiments of a different nature which could be applied with safety both to mother and child.

It was decided that the first requisite was to determine whether or not the fetus was capable of absorbing lipids from umbilical blood. Obviously if lipids were not taken up by the fetus as blood passed through it, then there was no need for the placenta to pass them on from the maternal blood stream. On the other hand if lipids were absorbed by the fetus from umbilical blood, then presumably the placenta must replenish the lost supply and such would be circumstantial evidence in favor of the "permeability" of the human placenta to lipids. When the term permeability is applied to lipids we do not mean simple diffusion as in the case of electrolytes. How the colloidal and insoluble lipid molecules pass through animal membranes is not understood but possibly it is through the intermediate formation of the semi-water soluble phospholipids.

PART A. FAT ABSORPTION BY THE HUMAN FETUS AT BIRTH

The procedure developed consisted in obtaining samples of blood from the umbilical vein and an umbilical artery immediately after parturition and comparing the lipid composition of each. The umbilical vein (Figure 1) carries blood from the placenta to the fetus while the umbilical arteries return blood from the fetus to the placenta after it has passed through the embryo. By comparing the lipid content of blood entering the fetus by the umbilical vein with the lipid content of blood leaving the fetus by the umbilical arteries, it may be found what lipids, if any, are added to or removed from the blood in its passage through the - fetus. 
This method was used as early as 1884 by Cohnstein and Zuntz (6) to investigate the physiology of the fetus. More recently it has been employed by Arstamianz (7), Blair-Bell et al. (8) and Naeslund (9). As far as the authors have been able to ascertain, no previous reports have appeared on the lipid composition of blood in both vessels. In 1913 Grigaut (10) reported in the course of a thesis that in three cases he found 11 to 12 per cent more cholesterol in the vein than in the artery and this was confirmed in 1926 by Arstamianz (7). Of the other lipids, ester cholesterol, free cholesterol, phospholipids, neutral fats, etc., apparently nothing has been reported.

All samples of blood were obtained from patients in the delivery rooms of the Strong Memorial Hospital. No attempt was made to select cases in regard to age, nationality, weight or parity; each patient was a normal, healthy woman at full term pregnancy and in labor. Since most obstetrical patients enter the maternity hospital in active labor, it was not possible to regulate the previous habitual diet of the patients nor to control the length of time between delivery and when the last meal was taken. Labor lasts from 15 to 24 hours and during this time most patients consume very little food so that the results may be considered approximately fasting values. To assure no harm to the health of the new born child, blood was not taken from the fetal end of the cord (umbilical artery) when the delivered infant

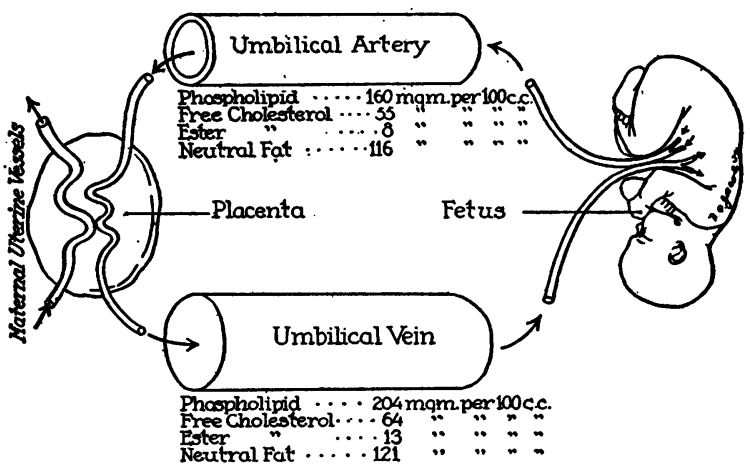

Fig. 1. Diagram Representing the Exchange of Lipids between the Human Fetus and Placenta at the Time of Parturition.

weighed under 3,000 grams and most of the infants were large, weighing between 3,500 and 4,500 grams. It is important to remember for the interpretation of the data to be presented below that all the new born infants were large and well nourished.

With the patient in the expulsive stage of labor, one of us "scrubbed in" on the delivery and was handed the child by the accoucher immediately after it had been removed from the uterus. The umbilical cord was clamped and cut immediately after delivery instead of waiting for the cord to stop pulsating in the orthodox manner. Cessation of pulsation in the umbilical cord signified the contraction of the umbilical arteries and under such circumstances it was found difficult to obtain a sample of blood from these vessels. For the same reason the new born child was quickly transferred to a heated crib and the cord stump (cut about 6 to 8 inches from the child) wrapped in warm towels.

The clamp holding the cord stump was then released and the cut end of the cord searched for an umbilical artery which was readily recognized by the pulsating spurts of blood emitted from it. The remaining cross section of the cord was clamped, excluding the artery from which blood was allowed to pump into a flask containing a small amount of half saturated sodium citrate solution. Ten to $20 \mathrm{cc}$. of blood were so obtained in about 5 minutes. A sample of venous blood was then taken from the maternal end of the cord with the placenta still attached in utero. The latter sample was considered to represent the venous blood entering the fetus. The contraction of the uterus was assumed to have little effect upon the lipid content of venous blood, an assumption which was substantiated in part by the finding of similar results in a case of caesarean section in which the uterus was not contracted. It was later found that the lipid concentration of venous blood slowly increases after the cord is clamped so that this sample was obtained as quickly as possible after delivery. The samples of whole blood from the artery and vein were then extracted and analysed for their lipid constituents using the Bloor oxidative microprocedures as modified by Boyd (11).

\section{RESULTS}

On each sample of blood the ten lipid values given by Boyd (11) were determined but for the sake of brevity and clarity only the essential values will be reported in detail. In Tables I to IV 
are listed the individual values respectively for phospholipid, free cholesterol, ester cholesterol and neutral fat. The remaining values (total lipid, total fatty acids, etc.) may be calculated from those given in the manner described by Boyd (11).

Fetal blood is known to contain three groups of lipids, namely phospholipids, neutral or glycerol fats and cholesterol and its esters. Phospholipids may be regarded as esters of fatty acids in combination with glycerol, a nitrogenous base or bases and phosphoric acid. The latter radicles impart to these substances the property of being partially soluble in water in which they form colloidal solutions. They also have a smaller molecular weight than most other lipids. For these reasons and from various experiments on fat absorption they are usually regarded as functioning in the transport of fatty acids.

TABLE I

Comparison of the phospholipid content of whole blood from the umbilical vein and the umbilical artery at birth

\begin{tabular}{|c|c|c|c|}
\hline Unit number & $\begin{array}{l}\text { Umbilical vein } \\
\text { (blood going } \\
\text { to fetus) }\end{array}$ & $\begin{array}{l}\text { Umbilical artery } \\
\text { (blood coming } \\
\text { from fetus) }\end{array}$ & $\begin{array}{l}\text { Phospholipid } \\
\text { absorbed } \\
\text { by fetus }\end{array}$ \\
\hline $\begin{array}{l}16033 \\
81576 \\
75842 \\
80482 \\
70067 \\
46488 \\
56521 \\
59820-A \\
59820-B \\
82597 \\
53777 \\
61916 \\
80368 \\
60631 \\
85939\end{array}$ & $\begin{array}{c}\text { mgm. per } 100 \text { cc. } \\
300 \\
250 \\
223 \\
219 \\
218 \\
213 \\
197 \\
192 \\
190 \\
185 \\
182 \\
180 \\
175 \\
168 \\
162\end{array}$ & \begin{tabular}{|c|} 
mgm. per 100 cc. \\
196 \\
223 \\
170 \\
183 \\
196 \\
83 \\
142 \\
83 \\
162 \\
163 \\
153 \\
170 \\
173 \\
140 \\
161
\end{tabular} & $\begin{array}{c}\text { mgm. per } 100 \text { cc. } \\
104 \\
27 \\
53 \\
36 \\
22 \\
130 \\
55 \\
109 \\
28 \\
22 \\
29 \\
10 \\
2 \\
28 \\
1\end{array}$ \\
\hline
\end{tabular}

The phospholipid (Table I) content of venous blood going to the fetus was found to range from 162 to $300 \mathrm{mgm}$. per cent with a mean value of 204 mgm. per cent. Blood leaving the fetus by the umbilical artery contained a lower range of values, 83 to $223 \mathrm{mgm}$. per cent and an average of $160 \mathrm{mgm}$. per cent; in each case the value in arterial blood was lower than in venous blood. If these values may be taken to represent the actual concentrations in blood entering and leaving the fetus then it may be calculated that the fetus absorbed from 1 to $130 \mathrm{mgm}$. of phospholipids from every $100 \mathrm{cc}$. of blood. The mean amount of phospholipids absorbed would be 44 mgm. per 100 cc. or 22 per cent of the phospholipids in blood sent to the fetus by the placenta. Considered in this light the results indicate that the fetus absorbs large amounts of phospholipids from umbilical blood.

TABLE II

Comparison of the free cholesterol content of whole blood from the umbilical artery and umbilical vein at birth

\begin{tabular}{l|c|c|c|c}
\hline \hline $\begin{array}{c}\text { Unit } \\
\text { number }\end{array}$ & $\begin{array}{c}\text { Umbilical } \\
\text { vein } \\
\text { (blood going } \\
\text { to fetus) }\end{array}$ & $\begin{array}{c}\text { Umbilical } \\
\text { artery } \\
\text { (blood } \\
\text { coming } \\
\text { from fetus) }\end{array}$ & $\begin{array}{c}\text { Free } \\
\text { cholesterol } \\
\text { absorbed } \\
\text { by fetus }\end{array}$ & $\begin{array}{c}\text { Free } \\
\text { cholesterol } \\
\text { given up } \\
\text { by fetus }\end{array}$ \\
\cline { 2 - 4 } $\begin{array}{c}\text { mgm. per } \\
100 \text { cc. }\end{array}$ & $\begin{array}{c}\text { mgm. per } \\
\text { 100 cc. }\end{array}$ & $\begin{array}{c}\text { mgm. per } \\
100 \text { cc. }\end{array}$ & $\begin{array}{c}\text { mgm. per } \\
100 \\
\text { cc. }\end{array}$ \\
61916 & 88 & 68 & 20 & 0 \\
75842 & 74 & 67 & 7 & 0 \\
16033 & 72 & 71 & 1 & 0 \\
81576 & 70 & 65 & 5 & 0 \\
70067 & 69 & 68 & 1 & 0 \\
46488 & 64 & 39 & 25 & 0 \\
85939 & 63 & 53 & 10 & 0 \\
$59820-A$ & 62 & 39 & 23 & 0 \\
53777 & 60 & 75 & 0 & 15 \\
$59820-B$ & 59 & 51 & 8 & 0 \\
80482 & 58 & 55 & 3 & 0 \\
56521 & 56 & 37 & 19 & 0 \\
80368 & 56 & 58 & 0 & 2 \\
82597 & 55 & 37 & 18 & 0 \\
60631 & 51 & 46 & 5 & 0 \\
\hline
\end{tabular}

Free cholesterol, Table II, exhibited changes similar to phospholipids. In all except two cases blood from the vein contained more free cholesterol than blood from the artery. In the former vessel the range was 51 to $88 \mathrm{mgm}$. per cent while in the latter it was 37 to $75 \mathrm{mgm}$. per cent giving an average of $64 \mathrm{mgm}$. per cent for the vein and 55 for the artery. Thus the fetus may be considered to have absorbed from 0 to $25 \mathrm{mgm}$. of free cholesterol per $100 \mathrm{cc}$. of blood, a mean absorption of $9 \mathrm{mgm}$. or 14 per cent of the free cholesterol going to the fetus from the placenta. It may thus be concluded that the fetus also absorbs free cholesterol though in appreciably smaller amounts than phospholipids. Cholesterol has the property of combining with fatty acids to produce cholesterol esters, substances which Bloor believes may act as transporters of fatty acids. That part of the total cholesterol which is united with fatty acids is designated ester cholesterol. 
TABLE III

Comparison of the ester cholesterol content of whole blood from the umbilical vein and the umbilical artery at birth

\begin{tabular}{l|c|c|c|c}
\hline \hline $\begin{array}{c}\text { Unit } \\
\text { number }\end{array}$ & $\begin{array}{c}\text { Umbilical } \\
\text { vein } \\
\text { (blood going } \\
\text { to fetus) }\end{array}$ & $\begin{array}{c}\text { Umbilical } \\
\text { artery } \\
\text { (blood } \\
\text { coming } \\
\text { from fetus) }\end{array}$ & $\begin{array}{c}\text { Ester } \\
\text { cholesterol } \\
\text { absorbed } \\
\text { by fetus }\end{array}$ & $\begin{array}{c}\text { Ester } \\
\text { cholesterol } \\
\text { given up } \\
\text { by fetus }\end{array}$ \\
\hline & $\begin{array}{c}\text { mgm. per } \\
100 \text { cc. }\end{array}$ & $\begin{array}{c}\text { mgm. per } \\
100 \text { cc. }\end{array}$ & $\begin{array}{c}\text { mgm. per } \\
100 \\
\text { cc. }\end{array}$ & $\begin{array}{c}\text { mgm. per } \\
100 \text { cc. }\end{array}$ \\
56521 & 49 & 16 & 33 & 0 \\
80368 & 34 & 13 & 21 & 0 \\
70067 & 28 & 7 & 21 & 0 \\
46488 & 26 & 6 & 20 & 0 \\
82597 & 19 & 5 & 14 & 0 \\
53777 & 15 & 5 & 10 & 0 \\
$59820-\mathrm{A}$ & 10 & 2 & 8 & 0 \\
75842 & 6 & 6 & 0 & 0 \\
16033 & 4 & 0 & 4 & 0 \\
80482 & 4 & 13 & 0 & 9 \\
81576 & 1 & 14 & 0 & 13 \\
61916 & 0 & 21 & 0 & 21 \\
85930 & 0 & 15 & 0 & 15 \\
60631 & 0 & 1 & 0 & 1 \\
$59820-B$ & 0 & 3 & 0 & 3 \\
\hline
\end{tabular}

Ester cholesterol, Table III, was found lower in the artery in 8 cases, lower in the vein in 6 cases and in 1 case was the same in both vessels. There appeared to be no relation between these changes until they were tabulated as in Table III according to the height of ester cholesterol in venous blood. It then became obvious that the more ester cholesterol in venous blood going to the fetus the more absorbed by the fetus. When the concentration of ester cholesterol in the umbilical vein fell below about $10 \mathrm{mgm}$. per cent then the fetus not only ceased to absorb this lipid but actually added some to the blood. This may conceivably represent an attempt on the part of the fetus to maintain a certain level of ester cholesterol in the blood. The results indicate that the fetus absorbs ester cholesterol providing there is more than a certain minimum concentration (10 mgm. per cent) in the blood.

Neutral fat, Table IV, behaved in a distinctly different manner from the other three lipids. In 9 cases there was more neutral fat in the venous blood and in 6 cases more in the arterial blood. No reason for the variation could be found such as differences in the concentration in venous blood, weight of fetus, etc. Very little is known about the function of neutral fat in blood: Boyd has shown that its concentration in blood is subject to marked variation under normal conditions
(11) and that it is more than doubled in value in plasma at the end of pregnancy (1). From the present results neutral fat may apparently be either absorbed or given up by the fetus. Its mean

TABLE IV

Comparison of the neutral fat content of whole blood from the umbilical vein and umbilical artery at birth

\begin{tabular}{l|c|c|c|c}
\hline \hline $\begin{array}{c}\text { Unit } \\
\text { number }\end{array}$ & $\begin{array}{c}\text { Umbilical } \\
\text { vein } \\
\text { (blood } \\
\text { going } \\
\text { to fetus) }\end{array}$ & $\begin{array}{c}\text { Umbilical } \\
\text { artery } \\
\text { (blood } \\
\text { coming } \\
\text { from fetus) }\end{array}$ & $\begin{array}{c}\text { Neutral fat } \\
\text { absorbed } \\
\text { by fetus }\end{array}$ & $\begin{array}{c}\text { Neutral fat } \\
\text { given up } \\
\text { by fetus }\end{array}$ \\
\cline { 2 - 5 } & $\begin{array}{c}\text { mgm. per } \\
100 \text { cc. }\end{array}$ & $\begin{array}{c}\text { mgm. per } \\
100 \\
\text { cc. }\end{array}$ & $\begin{array}{c}\text { mgm. per } \\
100 \text { cc. }\end{array}$ & $\begin{array}{c}\text { mgm. per } \\
100 \\
\text { cc. }\end{array}$ \\
81576 & 195 & 263 & 0 & 68 \\
16033 & 193 & 206 & 0 & 13 \\
82597 & 186 & 196 & 0 & 10 \\
85930 & 179 & 136 & 43 & 0 \\
61916 & 172 & 64 & 108 & 0 \\
80482 & 163 & 96 & 67 & 0 \\
$59820-B$ & 122 & 104 & 18 & 0 \\
60631 & 94 & 82 & 12 & 0 \\
53777 & 94 & 138 & 0 & 44 \\
80368 & 92 & 150 & 0 & 58 \\
75842 & 88 & 83 & 5 & 0 \\
$59820-B$ & 76 & 50 & 26 & 0 \\
70067 & 66 & 58 & 8 & 0 \\
46488 & 61 & 58 & 3 & 0 \\
56521 & 31 & 57 & 0 & 26 \\
\hline
\end{tabular}

values together with corresponding values for the other lipids have been given in Figure 1 ; the data given in this figure may be considered as a short summary of the results above.

Of particular interest among the cases studied were those of Unit Number 59820-A and -B. These were double ovum twins of the same sex and weight. One might expect to find the same amount of lipids going to and coming from each. Yet this was not the case. Twin A absorbed more phospholipids, more free cholesterol, more ester cholesterol and more neutral fat than Twin B. There findings in conjunction with the wide range of values for each lipid as given in Tables I to IV indicate that there is considerable variation from one fetus to another in respect to the absorption of lipids from umbilical blood.

\section{The composition of fatty acids in fetal blood}

In six cases iodine numbers were determined on the fatty acids of umbilical vein plasma. The values obtained for the iodine number of total fatty acids were $60,66,72,76,88$ and 119 or a mean of 80 . The average iodine number of total 
fatty acids in the plasma of adult normal and pregnant women is about the same, namely 86 (1). This indicates that the fatty acids of blood plasma are probably similar in composition in the fetus as in the adult. The iodine numbers of phospholipid fatty acids from the same plasma of fetal venous blood were found to be $53,58,96$, 94,126 and 149 or an average of 96 , somewhat lower than the corresponding value for adults, 120 (1). The phospholipids of fetal blood therefore probably contain more saturated fatty acids than phospholipids of adult plasma.

In two cases a sufficient amount of arterial blood was obtained to enable a comparison of iodine numbers in venous and arterial blood. In both cases the iodine number of phospholipid fatty acids was higher in arterial than venous blood, the values being respectively 176 to 149 and 142 to 58 . The results suggest that the fetus has a distinct preference for saturated fatty acids. Furthermore, the phospholipid fraction of arterial plasma gave no precipitation from ethereal solution with alcohol whereas a marked cloudiness developed in the solution of venous phospholipids. Since alcohol precipitates cephalin from ethereal solution and does not affect lecithin these preliminary tests suggest that the fetus has an avidity for cephalin in particular. Cephalin is found in appreciable amounts in brain and nerve tissue.

The results presented in Part A indicate clearly that whole blood collected from the umbilical vein immediately after delivery contains a greater concentration of most lipids than blood collected from the umbilical artery of the infant also collected immediately after delivery. Phospholipids are markedly lower in value in arterial blood, free cholesterol somewhat less so, ester cholesterol usually lower but depending on the concentration in the vein and neutral fat varying one way or the other. When the pathway of the fetal circulation, as depicted in Figure 1, is taken into consideration it appears reasonable to interpret these results as signifying an absorption of the first three of these lipids by the fetus from umbilical blood. The fact that all lipids were not reduced to the same relative extent in arterial blood indicates that the results are not due to a simple dilution of venous blood in its passage through the fetus. Since the samples of blood were collected immediately after the cord had been cut it is probable that fat was absorbed by the fetus at the same rate as when the umbilical circulation was intact. We may therefore conclude that the human fetus at birth absorbs from umbilical blood phospholipids, free cholesterol and cholesterol esters and occasionally neutral fat also.

By analysing the results more closely, it is possible to arrive at an approximate idea of the amount of lipids being absorbed by the fetus per day. It will be recalled that blood was taken from the umbilical artery within 5 minutes of the time that the cord was clamped and cut. The fetus thus had 5 minutes in which to absorb lipids from its blood stream before all of the arterial sample of blood was secured. If we assume that no lipids were added to the blood by the fetus in this interval then we may calculate the total amount of lipids absorbed in 5 minutes, in an hour or in a day. The concentration of lipids in arterial blood subtracted from the concentration in the vein will thus roughly indicate the amount of lipids absorbed from $100 \mathrm{cc}$. of blood in five minutes. Multiplying this value by $2 \frac{1}{2}$ will give the total amount of lipid absorbed from the entire fetal blood stream which is usually reckoned as $250 \mathrm{cc}$. in the average infant.

Applying these calculations to phospholipid values it may be found that an average large well nourished human infant at delivery absorbs 44 mgm. of phospholipids per $100 \mathrm{cc}$. of blood per 5 minutes or approximately 30 grams per $250 \mathrm{cc}$. per 24 hours. Although this is only an approximation it is probably fairly correct: there are certain factors which would lower it and certain which would increase it. The important point is that it indicates that the human fetus at birth absorbs very large quantities of this lipid; 30 grams represents three times as much phospholipid as the maternal blood stream contains at any one time. In a similar manner it may be calculated that free cholesterol is absorbed at the average rate of 6 to 7 grams per day and cholesterol esters (ester cholesterol plus cholesterol ester fatty acids) at about the same rate. In all, 40 to 50 grams of these lipids are absorbed from umbilical blood per day by the human fetus. Part of this fat is no doubt used as fuel in metabolism and part stored in the fat depots.

As previously stated, it is probable that lipid 
absorption by the fetus is similar just before the cord is cut to what it is just after. Before the cord is clamped and cut, blood travels in a closed circuit from the placenta to the fetus and back to the placenta. If the fetus removes lipids from this blood, then lipids must be added by the placenta to make up for the loss. The experimental data given may be taken to prove this fact. By referring to Figure 1 it may be seen that arterial blood may be regarded as blood entering the placenta and venous blood as blood leaving the placenta. Since venous blood has been shown to contain increased amounts of most lipids, it may be concluded that these substances are added to umbilical blood in its passage through the placenta. Additional evidence that the placenta actually does add these lipids to umbilical blood will now be offered.

\section{PART B. THE ADDITION OF LIPIDS TO UMBILICAL BLOOD BY THE PLACENTA AT BIRTH}

When the human fetus is delivered, the umbilical cord is clamped and cut. For a period of from 10 to 30 minutes, the placenta remains attached to the uterine wall before separating and being expelled by the recurrence of uterine contractions. During most of this interval the placental and maternal blood remain in the same relationship as in the latter part of pregnancy. Hence if lipids are added to the placental blood by the maternal blood stream, they will continue to do so until the placenta separates. The umbilical cord being clamped, circulation of blood through the placenta and fetus has ceased and any lipids which are added to umbilical blood will not be removed by the fetus. As a result these lipids will accumulate in placental blood and raise the concentration of lipids there. Thus, if a sample of umbilical blood is obtained immediately after the child is delivered when the cord is cut and a second sample obtained 10 to 30 minutes later when the placenta separates from the uterine wall, there should be a greater concentration of lipids in the second sample than in the first providing the premise is correct that the placenta adds lipids to umbilical blood.

Such a procedure was adopted. Twenty-five to 50 cc. of blood (Sample 1) were taken from the umbilical vein immediately after the cord had been cut. The uterus was then palpated through the mother's abdomen until the placenta was noted to separate from the uterine wall. Then the uterus was compressed and as much blood as possibleusually 50 to $75 \mathrm{cc}$.-collected from the umbilical vein in another flask (Sample 2). Each sample of blood was separately extracted and analysed for its lipid content.

TABLE V

Variation in the phospholipid content of whole blood from the umbilical vein between the time of delivery and 10 to 30 minutes later at the time the placenta separates from the uterus

\begin{tabular}{c|c|c|c|c}
\hline \hline $\begin{array}{c}\text { Case } \\
\text { number }\end{array}$ & At delivery & $\begin{array}{c}\text { At placental } \\
\text { separation }\end{array}$ & $\begin{array}{c}\text { Phospholipid } \\
\text { added by } \\
\text { placenta }\end{array}$ & $\begin{array}{c}\text { Phospholipid } \\
\text { removed by } \\
\text { placenta }\end{array}$ \\
\cline { 2 - 5 } & $\begin{array}{c}\text { mgm. per } \\
100 \text { cc. }\end{array}$ & $\begin{array}{c}\text { mgm. per } \\
100 \text { cc. }\end{array}$ & $\begin{array}{c}\text { mgm. per } \\
100 \text { cc. }\end{array}$ & $\begin{array}{c}\text { mgm. per } \\
100 \text { cc. }\end{array}$ \\
1 & 162 & 192 & 30 & 0 \\
2 & 165 & 184 & 19 & 0 \\
3 & 167 & 197 & 30 & 0 \\
4 & 168 & 219 & 41 & 0 \\
5 & 175 & 204 & 29 & 0 \\
6 & 182 & 236 & 52 & 0 \\
7 & 185 & 201 & 16 & 0 \\
8 & 190 & 163 & 0 & 27 \\
9 & 192 & 253 & 61 & 0 \\
10 & 197 & 212 & 15 & 0 \\
11 & 213 & 226 & 13 & 0 \\
12 & 218 & 222 & 4 & 0 \\
13 & 219 & 225 & 6 & 0 \\
14 & 223 & 210 & 0 & 13 \\
\hline
\end{tabular}

Phospholipid, Table V, again exhibited the most consistent and extensive changes. In twelve out of fourteen cases, Sample 2 contained more phospholipids than Sample 1. At delivery the phospholipid concentration in whole blood from the umbilical vein varied between 162 and $223 \mathrm{mgm}$. per cent with a mean of $190 \mathrm{mgm}$. per cent. At the time of placental separation half an hour later, the range was 163 to $236 \mathrm{mgm}$. per cent with a mean of $210 \mathrm{mgm}$. per cent and an average addition of $20 \mathrm{mgm}$. of phospholipid per $100 \mathrm{cc}$. of blood. Since, as will be shown, the other lipids were not increased at the same rate, the increase in phospholipid cannot have been due simply to the placenta removing water from the umbilical blood. It appears logical to conclude that these results indicate phospholipid is actually added to umbilical blood between the time of delivery and the time of placental separation, and it is probable that such an addition also occurs before delivery. That phospholipid is added to umbilical blood by the placenta explains how phospholipid is restored to umbilical blood when removed by the fetus. 
TABLE VI

Variation in the free cholesterol content of whole blood from the umbilical vein between the time of delivery and 10 to 30 minutes later at the time the placenta separates from the uterus

\begin{tabular}{c|c|c|c|c}
\hline \hline $\begin{array}{c}\text { Case } \\
\text { number }\end{array}$ & $\begin{array}{c}\text { At } \\
\text { delivery }\end{array}$ & $\begin{array}{c}\text { At placental } \\
\text { separation }\end{array}$ & $\begin{array}{c}\text { Free } \\
\text { cholesterol } \\
\text { added by } \\
\text { placenta }\end{array}$ & $\begin{array}{c}\text { Free } \\
\text { cholesterol } \\
\text { removed by } \\
\text { placenta }\end{array}$ \\
\hline & $\begin{array}{c}\text { mgm. per } \\
100 \text { cc. }\end{array}$ & $\begin{array}{c}\text { mgm. per } \\
100 \text { cc. }\end{array}$ & $\begin{array}{c}\text { mgm. per } \\
100 \text { cc. }\end{array}$ & $\begin{array}{c}\text { mgm. per } \\
100 \text { cc. }\end{array}$ \\
1 & 49 & 57 & 8 & 0 \\
2 & 50 & 66 & 16 & 0 \\
3 & 51 & 51 & 0 & 0 \\
4 & 55 & 67 & 12 & 0 \\
5 & 56 & 61 & 15 & 0 \\
6 & 58 & 72 & 14 & 0 \\
7 & 59 & 53 & 0 & 6 \\
8 & 60 & 69 & 9 & 0 \\
9 & 62 & 78 & 16 & 0 \\
10 & 63 & 67 & 4 & 0 \\
11 & 64 & 65 & 1 & 0 \\
12 & 66 & 72 & 6 & 0 \\
13 & 69 & 66 & 0 & 3 \\
14 & 74 & 73 & 0 & 1 \\
\hline
\end{tabular}

Free cholesterol, Table VI, was also more concentrated in Sample 2 in the majority of cases. The average value for free cholesterol at delivery was $60 \mathrm{mgm}$. per cent and at placental separation 65 mgm. per cent. In 72 per cent of cases Sample 2 contained more free cholesterol than Sample 1 , in 7 per cent there was no change and in 21 per cent free cholesterol was lower in the second sample of blood. Individual differences between the two samples were small as would be expected. The results may be interpreted as signifying that the human placenta adds free cholesterol to umbilical blood.

Ester cholesterol, Table VII, behaved in a manner similar to free cholesterol. The mean value for ester cholesterol at delivery was $16 \mathrm{mgm}$. per cent and at placental separation 19 mgm. per cent. In 64 per cent of cases ester cholesterol was increased in Sample 2, in 7 per cent unchanged and in 29 per cent decreased. It may therefore be concluded that cholesterol esters are often added to umbilical blood by the placenta.

Neutral fat, Table VIII, again exhibited marked variation. In 50 per cent of cases Sample 2 contained more neutral fat than Sample 1, in 43 per cent there was less and in 7 per cent both samples contained the same amount. The average value at birth was $108 \mathrm{mgm}$. per cent and at placental separation $88 \mathrm{mgm}$. per cent. The results indicate that neutral fat may be either added to or removed from umbilical blood by the placenta. The factor influencing the direction of the exchange was not found.

TABLE VII

Variation in the ester cholesterol content of whole blood from the umbilical vein between the time of delivery and 10 to 30 minutes later at the time the placenta separates from the uterus

\begin{tabular}{c|c|c|c|c}
\hline \hline $\begin{array}{c}\text { Case } \\
\text { number }\end{array}$ & $\begin{array}{c}\text { At } \\
\text { delivery }\end{array}$ & $\begin{array}{c}\text { At placental } \\
\text { separation }\end{array}$ & $\begin{array}{c}\text { Ester } \\
\text { cholesterol } \\
\text { added by } \\
\text { placenta }\end{array}$ & $\begin{array}{c}\text { Ester } \\
\text { cholesterol } \\
\text { removed by } \\
\text { placenta }\end{array}$ \\
\cline { 2 - 5 } & $\begin{array}{c}\text { mgm. per } \\
100 \text { cc. }\end{array}$ & $\begin{array}{c}\text { mgm. per } \\
100 \text { cc. }\end{array}$ & $\begin{array}{c}\text { mgm. per } \\
100 \text { cc. }\end{array}$ & $\begin{array}{c}\text { mgm. per } \\
100 \text { cc. }\end{array}$ \\
1 & 0 & 0 & 0 & 0 \\
2 & 0 & 19 & 19 & 0 \\
3 & 0 & 21 & 21 & 0 \\
4 & 4 & 15 & 11 & 0 \\
5 & 6 & 17 & 11 & 0 \\
6 & 10 & 1 & 0 & 9 \\
7 & 12 & 15 & 3 & 0 \\
8 & 15 & 13 & 0 & 2 \\
9 & 18 & 21 & 3 & 0 \\
10 & 20 & 27 & 7 & 0 \\
11 & 26 & 30 & 4 & 0 \\
12 & 28 & 30 & 2 & 0 \\
13 & 34 & 32 & 0 & 2 \\
14 & 49 & 27 & 0 & 22 \\
\hline
\end{tabular}

TABLE VIII

Variation in the neutral fat content of whole blood from the umbilical vein between the time of delivery and 10 to 30 minutes later at the time the placenta separates from the uterus

\begin{tabular}{c|c|c|c|c}
\hline \hline $\begin{array}{c}\text { Case } \\
\text { number }\end{array}$ & At delivery & $\begin{array}{c}\text { At } \\
\text { placental } \\
\text { separation }\end{array}$ & $\begin{array}{c}\text { Neutral fat } \\
\text { added by } \\
\text { placenta }\end{array}$ & $\begin{array}{c}\text { Neutral fat } \\
\text { removed by } \\
\text { placenta }\end{array}$ \\
\cline { 2 - 4 } & $\begin{array}{c}\text { mgm. per } \\
100 \text { cc. }_{\text {cla }}\end{array}$ & $\begin{array}{c}\text { mgm. per } \\
100 \text { cc. }\end{array}$ & $\begin{array}{c}\text { mgm. per } \\
100 \text { cc. }\end{array}$ & $\begin{array}{c}\text { mgm. per } \\
100 \text { cc. }\end{array}$ \\
1 & 31 & 31 & 0 & 0 \\
2 & 47 & 4 & 0 & 43 \\
3 & 61 & 36 & 0 & 25 \\
4 & 66 & 74 & 8 & 0 \\
5 & 76 & 0 & 0 & 76 \\
6 & 88 & 92 & 4 & 0 \\
7 & 92 & 102 & 10 & 0 \\
8 & 94 & 23 & 0 & 71 \\
9 & 94 & 157 & 63 & 0 \\
10 & 108 & 100 & 0 & 8 \\
11 & 122 & 36 & 0 & 86 \\
12 & 163 & 181 & 18 & 0 \\
13 & 179 & 195 & 16 & 0 \\
14 & 186 & 196 & 10 & 0 \\
\hline
\end{tabular}

The results of Part $\mathrm{B}$ demonstrate that blood from the umbilical vein at placental separation contains more phospholipids in practically 100 per cent of cases, more free cholesterol in about 75 per cent of cases, more cholesterol esters in about 
two thirds of the cases and more neutral fat in only one half the cases than at the time of delivery. These results consistently agree with the findings in Part A. Phospholipids are of paramount importance in the exchange of lipids between the placenta and the fetus: they are added to umbilical blood by the placenta and absorbed by the fetus. Free cholesterol is also absorbed by the fetus but in smaller amounts; and in only three quarters of the cases studied could the placenta be shown to add free cholesterol to umbilical blood. Ester cholesterol is absorbed by the fetus providing there is more than about $10 \mathrm{mgm}$. per cent in its blood; when the concentration falls below $10 \mathrm{mgm}$. per cent the placenta adds large amounts but if the concentration is above $10 \mathrm{mgm}$. per cent the placenta may either add or subtract a few mgm. Apparently both the placenta and the fetus take part in keeping the value of ester cholesterol in umbilical blood at about $10 \mathrm{mgm}$. per cent. Neutral fat may be either absorbed or given up both by the placenta and the fetus; what factors govern the direction of the exchange are not apparent from the results to date.

\section{The rôle of the white blood cells}

In view of some of the older theories which ascribed to blood leukocytes an important function in fat absorption from the intestine, it was decided to investigate the lipid content of these cells in the fetal circulation. The methods of separation and analysis used were those of Boyd (12).

In 11 cases sufficient blood was obtained from the umbilical vein to perform a complete analysis on the leukocytes and the results are given in Table IX. The outstanding difference between the lipid content of leukocytes in the fetal blood and those of adult blood as previously reported (12) is that the fetal white cells contain smaller amounts of all the various lipid constituents, approximately one half the values in adults. The difference was less marked though still distinctly lower than the concentration of lipids in the leukocytes of pregnant women in whom the values are somewhat lower than in non-pregnant women (13).

Differential leukocyte counts in fetal and infant blood have shown that there is a greater percentage of lymphocytes in the young, as much as 50 per cent of the total leukocytes. The low lipid content is possibly related to this greater proportion of lymphocytes. The blood leukocytes in a case of chronic lymphatic leukemia studied by one of us (E. M. B.) gave evidence of low lipid values and the leukocytes were composed chiefly of lymphocytes.

TABLE IX

The lipid composition of the white blood cells in umbilical vein blood at birth

\begin{tabular}{|c|c|c|c|c|c|c|}
\hline \multirow{3}{*}{$\begin{array}{c}\text { Case } \\
\text { num- } \\
\text { ber }\end{array}$} & \multirow{3}{*}{$\begin{array}{l}\text { Total } \\
\text { lipid }\end{array}$} & \multicolumn{5}{|c|}{ Composition of total lipid } \\
\hline & & \multirow{2}{*}{$\underset{\text { fat }}{\text { Neutral }}$} & \multicolumn{3}{|c|}{ Cholesterol } & \multirow{2}{*}{$\begin{array}{l}\text { Phos- } \\
\text { pholipid }\end{array}$} \\
\hline & & & Total & Ester & Free & \\
\hline & $\begin{array}{c}\text { mgm. per } \\
100 \\
\text { grams }\end{array}$ & $\begin{array}{c}\text { mgm. per } \\
100 \\
\text { grams }\end{array}$ & $\begin{array}{c}\text { mgm. per } \\
100 \\
\text { grams }\end{array}$ & $\begin{array}{c}\text { mgm. per } \\
100 \\
\text { grams }\end{array}$ & $\begin{array}{c}\text { mgm. per } \\
100 \\
\text { grams }\end{array}$ & $\begin{array}{c}\text { mgm. per } \\
100 \\
\text { grams }\end{array}$ \\
\hline $\begin{array}{r}1 \\
2 \\
3 \\
4 \\
5 \\
6 \\
7 \\
8 \\
9 \\
10 \\
11 \\
\text { Mean }\end{array}$ & $\begin{array}{c}1540 \\
1105 \\
932 \\
845 \\
793 \\
759 \\
719 \\
691 \\
691 \\
686 \\
566 \\
848\end{array}$ & $\begin{array}{r}660 \\
394 \\
0 \\
158 \\
112 \\
0 \\
82 \\
0 \\
0 \\
0 \\
41 \\
132\end{array}$ & $\begin{array}{l}170 \\
239 \\
431 \\
185 \\
156 \\
201 \\
170 \\
163 \\
196 \\
174 \\
174 \\
205\end{array}$ & $\begin{array}{r}0 \\
0 \\
280 \\
63 \\
74 \\
9 \\
0 \\
48 \\
27 \\
0 \\
58 \\
51\end{array}$ & $\begin{array}{r}179 \\
243 \\
151 \\
122 \\
82 \\
192 \\
172 \\
115 \\
169 \\
174 \\
116 \\
156\end{array}$ & $\begin{array}{l}710 \\
472 \\
313 \\
460 \\
475 \\
552 \\
467 \\
496 \\
477 \\
512 \\
342 \\
480\end{array}$ \\
\hline
\end{tabular}

In only 4 cases was sufficient blood obtained from the umbilical artery to permit a lipid analysis of the white blood cells. All the values found were within the same range as the venous leukocytes. Comparing the lipid composition of the venous leukocytes to that of the arterial in the same infant, each lipid was found changed after passing through the fetus but in the 4 cases studied no consistent variation for any lipid could be established. Nor was there any consistent difference in the lipid values of the venous leukocytes between the time of delivery and the time of placental separation. In fact neither by comparing individual differences nor general trends and means could any evidence be obtained that the blood leukocytes aided the transfer of lipids between the placenta and the fetus.

\section{SUMMARY}

Evidence has been presented that certain lipids are added to umbilical blood by the placenta and removed or absorbed by the fetus.

(1) Whole blood from the umbilical artery at 
birth contained 22 per cent less phospholipids and 14 per cent less free cholesterol than whole blood from the umbilical vein. Ester cholesterol was also lower in arterial blood but only when venous blood contained over $10 \mathrm{mgm}$. per cent of this lipid. Neutral fat was lower in about half the cases and higher in the other half. The results were considered to signify that phospholipid and free cholesterol are regularly absorbed by the human fetus from umbilical blood at birth, ester cholesterol providing that there is sufficient (over 10 mgm. per cent) to be absorbed while neutral fat may be either absorbed or given up. It was estimated that over 40 grams, 75 per cent of which is phospholipids, of these substances are absorbed in 24 hours by an average large, well nourished human fetus at birth.

(2) Whole blood which lies in the placenta between the time that the cord is clamped and the time that the placenta separates from the uterine wall was found to acquire additional amounts of phospholipids in 12 out of 14 cases, free cholesterol in three quarters of the cases, ester cholesterol in two thirds of the cases and neutral fat in half the cases. It was concluded that the placenta adds all of these substances to umbilical blood and may remove some of them, especially neutral fat. Phospholipids, free cholesterol and ester cholesterol therefore pass in general in one direction, namely from the placenta to the fetus, while neutral fat may pass in either direction.

(3) The composition of fatty acids in plasma from the umbilical vein were found similar, in respect to their iodine number, to those of adult plasma except phospholipid fatty acids which are apparently more saturated in the fetal circulation. It is probable that the fetus absorbs the more saturated phospholipid fatty acids and that it has an especial avidity for the cephalin fraction of the phospholipids.

(4) The white blood cells of fetal blood contain about one half the lipid concentration of adult leukocytes which is probably due to the greater proportion of lymphocytes in the blood of the fe- tus at birth. No evidence was obtained that they function in the transport of fat from the placenta to the fetus or vice versa.

\section{BIBLIOGRAPHY}

1. Boyd, E. M., The lipemia of pregnancy. J. Clin. Invest., 1934, 13, 347.

2. Needham, J., Chemical Embryology. Cambridge University Press, Cambridge, 1931.

3. Slemons, J. M., and Stander, H. J., The lipoids of maternal and fetal blood at the conclusion of labor. Bull. Johns Hopkins Hosp., 1923, 34, 7.

4. Mayer, A., Biologie der Placenta. I. Physiologischer Teil. Arch. f. Gynäk., 1929, 137, 1.

5. Schlossmann, H., Der Stoffaustausch zwischen Mütter und Frucht durch die Placenta. Ergebn. d. Physiol., 1932, 34, 741.

6. Cohnstein, J., and Zuntz, N., Untersuchungen über das Blut, den Kreislauf und die Athmung beim Säugethier-Fötus. Arch. f. d. ges. Physiol., 1884, 34, 173.

7. Arstamianz, G., Uber Cholesterinämie bei Schwangeren. Zentralbl. f. Gynäk., 1926, 50, 3342.

8. Blair-Bell, W., Cunningham, L., Jowett, M., Millet, H., and Brooks, J., The metabolism and acidity of the fetal tissues and fluids. Brit. M. J., 1928, 126.

9. Naeslund, J., Untersuchungen über den Ubergang $\mathrm{N}$-haltiger Stoff vom Fötus auf die Mütter. Acta Obst. et gynec. Scandinav., 1931, 11, 474.

10. Grigaut, A., Cycle de la Cholestérinémie. Thèse de Paris, 1913. ref. Hinglais, H., and Govaerts, J., Gynéc. et obst., 1930, 22, 137.

11. Boyd, E. M., A differential lipid analysis of blood plasma in normal young women by micro-oxidative methods. J. Biol. Chem., 1933, 101, 323.

12. Boyd, E. M., The lipid composition of the white blood cells in normal young women. J. Biol. Chem., 1933, 101, 623.

13. Boyd, E. M., The lipid composition of the white blood cells in women during pregnancy, lactation and the puerperium. Surg., Gynec. and Obst., 1934, 59, 744.

14. Bickenbach, W., and Rupp, H., Das Verhalten der Fette bei ihrem Durchtritt durch die Placenta. Klin. Wchnschr., 1931, 10, 63.

15. Sinclair, R. G., The permeability of the rat's placenta to fat. Am. J. Physiol., 1933, 103, 73.

16. Chaikoff, I. L., and Robinson, A., Studies in fetal fat. I. The influence of high and low fat diets on the quantity of fat formed in the fetus of the rat. J. Biol. Chem., 1933, 100, 13. 